\title{
Influence of mariculture on the distribution of dissolved inorganic selenium in Sanggou Bay, northern China
}

\author{
Yan Chang ${ }^{1,2, *}$, Jing Zhang ${ }^{2}$, Jianguo $\mathbf{Q u}^{2}$, Zengjie Jiang ${ }^{3}$, Ruifeng Zhang ${ }^{2}$ \\ ${ }^{1}$ School of Ecological and Environmental Sciences, East China Normal University, Shanghai 200062, PR China \\ ${ }^{2}$ State Key Laboratory of Estuarine and Coastal Research, East China Normal University, Shanghai 200062, PR China \\ ${ }^{3}$ Key Laboratory for Sustainable Utilization of Marine Fisheries Resources, Ministry of Agriculture, \\ Yellow Sea Fisheries Research Institute, Chinese Academy of Fishery Sciences, Qingdao 266071, PR China
}

\begin{abstract}
Selenium is known as a 'double-edged sword' element on account of its dual beneficial and toxic effects on organisms, depending on its concentration and chemical form. Dissolved inorganic selenium (DISe) concentration in the water column and selenium content in biological species were investigated in a typical aquacultural area in Sanggou Bay, China. In addition to sampling within Sanggou Bay, the main sources of DISe into Sanggou Bay were sampled to estimate selenium transport from different sources. Results showed that DISe and selenite [Se(IV)] concentrations averaged, respectively, $0.69 \mathrm{nmol} \mathrm{l}^{-1}$ and $0.28 \mathrm{nmol}^{-1}$, with ranges 0.21 to $1.36 \mathrm{nmol}$ $\mathrm{l}^{-1}$ and 0.07 to $0.58 \mathrm{nmol} \mathrm{l}^{-1}$, in the surface water of Sanggou Bay. The DISe in Sanggou Bay remained well below the toxic levels. The DISe and Se(IV) concentrations varied temporally, with lows in summer and highs in spring and autumn. Concentrations showed strong horizontal gradients from the coast to offshore areas within the bay, as significantly influenced by the intensive and widespread seaweeds and bivalves aquaculture activity in the bay. The highest selenium content (mean $\pm \mathrm{SD})$ was observed in scallops $\left(3.6 \pm 0.7 \mu \mathrm{g} \mathrm{g}^{-1}\right)$, followed by oyster $\left(1.6 \pm 0.4 \mu \mathrm{g} \mathrm{g}^{-1}\right)$, phytoplankton $\left(0.9 \pm 0.3 \mu \mathrm{g} \mathrm{g}^{-1}\right)$, Gracilaria lemaneiformis $\left(0.063 \pm 0.008 \mu \mathrm{g} \mathrm{g}^{-1}\right)$ and kelp $(0.032 \pm$ $0.005 \mathrm{\mu g} \mathrm{g}^{-1}$ ). The main source of DISe in Sanggou Bay was water exchange with the Yellow Sea, whereas the most important sink was biological activity, which removed $53 \pm 12 \%$ of the incoming selenium from bay waters.
\end{abstract}

KEY WORDS: Dissolved inorganic selenium $\cdot$ Aquaculture $\cdot$ Seaweed $\cdot$ Bivalve $\cdot$ Sanggou Bay

\section{INTRODUCTION}

Selenium is known to be a 'double-edged sword' element, having one of the narrowest ranges of beneficent effects of all elements, varying between dietary deficiency $\left(<40 \mu \mathrm{g} \mathrm{d}^{-1}\right)$ and toxicity $(>400 \mu \mathrm{g}$ $\mathrm{d}^{-1}$ ) (Price et al. 1987, Fernández-Martínez \& Charlet 2009). Selenium is an essential trace element required in the diets of many organisms for normal growth and physiological functions (Lin \& Shiau 2005, Lobanov et al. 2009). It serves as a component of the enzyme glutathione peroxidase to protect cell

${ }^{*}$ Corresponding author: cyyc2010@126.com membranes against oxidative damage (Rotruck et al. 1973). However, excess dietary selenium behaves as an analogue to sulfur, erroneously replacing sulfur atoms in proteins; this leads to distortion of the structure and eventual dysfunction of enzymes and proteins (Simmons \& Wallschläger 2005). The biogeochemical cycle of selenium in aquatic systems has attracted considerable attention in recent decades (Cutter \& Bruland 1984, Cutter \& Cutter 1995, 2001, Abdel-Moati 1998, Yao \& Zhang 2005).

Similar to other trace elements, the chemical form has an important influence on the fate of the sele-

(C) The authors 2016. Open Access under Creative Commons by Attribution Licence. Use, distribution and reproduction are unrestricted. Authors and original publication must be credited. 
nium. To understand the biological function of selenium in aquatic organisms, it is necessary to know the levels of different selenium species in the water column. The behavior of selenium in natural waters is complicated by the presence of several oxidation states (-II, IV, VI) and organic species (Conde \& Sanz Alaejos 1997). Selenite [Se(IV)] and selenate $[\mathrm{Se}(\mathrm{VI})]$ are depleted in surface water and enriched in deep water, and exhibit a nutrient-type profile consistent with other bioactive trace elements in the ocean (Cutter \& Bruland 1984, Cutter \& Cutter 1995, 2001).

China is one of the largest marine shellfish and seaweed producers in the world (Zhang et al. 2009). Sanggou Bay, located in Shandong Province, is an important aquacultural production area in China (Guo et al. 1999) (see Fig. 1), and is mainly used to culture seaweed and bivalves (Fang et al. 1996). Sanggou Bay has been the focus of research for $\sim 20 \mathrm{yr}$, and extensive studies have been conducted on hydrodynamic characteristics (Zhao et al. 1996), sediment chemistry (Cai et al. 2003), nutrients (Liu et al. 2004), heavy metals (Jiang et al. 2008), ecosystem services (Zheng et al. 2009), and the sustainable management of aquaculture (Zhang et al. 2009, Shi et al. 2011). Until now, however, little research has been conducted on selenium in the aquacultural areas. Studies have indicated that selenium can stimulate the growth of seaweed (Fries 1982, Horne 1991) and that, through metabolism, seaweed can accumulate over 50 times more inorganic selenium in Se(IV) enriched culture medium than in seawater (Yan et al. 2004). In addition, the selenium assimilation efficiency of bivalves can be as high as 70 to $95 \%$ when feeding on the cytoplasm of the prey alga (Wang \& Fisher 1996, Reinfelder et al. 1997); these levels may be threatening to upper trophic level birds and fish (Lemly 1995). Further studies are necessary to investigate the distributions of selenium species in aquaculture areas like Sanggou Bay, and to understand the mechanisms controlling the speciation of selenium in natural waters more generally.

The goal of this research was to investigate the distribution of dissolved inorganic selenium (DISe), selenite [Se(IV)] and selenate [Se(VI)] in Sanggou Bay, and in the river and groundwater along the coastline of the bay, in order to (1) determine the distribution of inorganic selenium species under different aquaculture conditions, and (2) estimate the input and output fluxes of selenium species. The results of this study will improve understanding of how the mariculture of seaweed and bivalves affects selenium biogeochemistry in aquacultural areas.

\section{MATERIALS AND METHODS}

\section{Study area}

Sanggou Bay is situated on the eastern tip of Shandong Peninsula to the northwest of the Yellow Sea $\left(37^{\circ} 01^{\prime}\right.$ to $37^{\circ} 09^{\prime} \mathrm{N}, 122^{\circ} 24^{\prime}$ to $\left.122^{\circ} 35^{\prime} \mathrm{E}\right)$, with a total area of approximately $144 \mathrm{~km}^{2}$ and mean depth of $7.5 \mathrm{~m}$ (Zhang et al. 2009). The bay has been used for aquaculture with seaweed and bivalves in different regions for $>30 \mathrm{yr}$. Monoculture of seaweeds, including kelp Saccharina japonica and Gracilaria lemaneiformis, occurs mainly near the mouth of the bay (hereafter 'S-region') from December to May (winter and spring) and from June to November (summer and autumn), respectively. Monoculture of bivalves (in the 'B-region'), including scallops (Chlamys farreri) and oysters (Crassostrea gigas), is mainly located near the end of the bay, while the middle part of the bay is occupied by seaweed-bivalve polyculture ('SB-region') (Fig. 1). The annual production of kelp and G. lemaneiformis is approximately $84.5 \times 10^{3}$ and $25.4 \times 10^{3} \mathrm{t}$ dry weight, respectively, while the annual production of bivalves is approximately $75 \times 10^{3} \mathrm{t}$ (Rongcheng Fisheries Technology Extension Station 2012). The rivers that enter the bay include the $\mathrm{Gu}$ (Chinese name: Guhe), Yatou (Yatouhe), Sanggan (Sangganhe), and Shili (Shilihe) rivers, as well as several other smaller creeks. The annual discharge of these seasonal rivers is from $0.17 \times 10^{9}$ to $0.23 \times 10^{9}$ $\mathrm{m}^{3}$ (Editorial Board of Annals of Bays in China 1991).

\section{Sample collection}

Samples were collected from marine areas in and adjacent to Sanggou Bay and from major rivers and groundwater along the coastline of the bay. Marine samples were collected during cruises in Sanggou Bay from 22 to 26 April (spring), 21 to 29 July (summer), and 17 to 20 October (autumn) of 2013, to investigate selenium levels in different seasons and various aquacultural activities. During each cruise, approximately 21 marine stations (Stns SG1 to SG19) were sampled (Fig. 1). Surface water was collected upstream and to the side of the boat while the boat moved forward, using a plastic pole sampler 3 to $4 \mathrm{~m}$ in length with an acid-cleaned polyethylene bottle attached to the end. Near-bottom water samples were taken with a 51 organic glass hydrophore. Sediment cores (about 0 to $4 \mathrm{~cm}$ depth) were collected using a box core $(15 \times 15 \mathrm{~cm})$ at Stns SG5 and SG6 in July 2013. Porewaters were extracted and filtered 


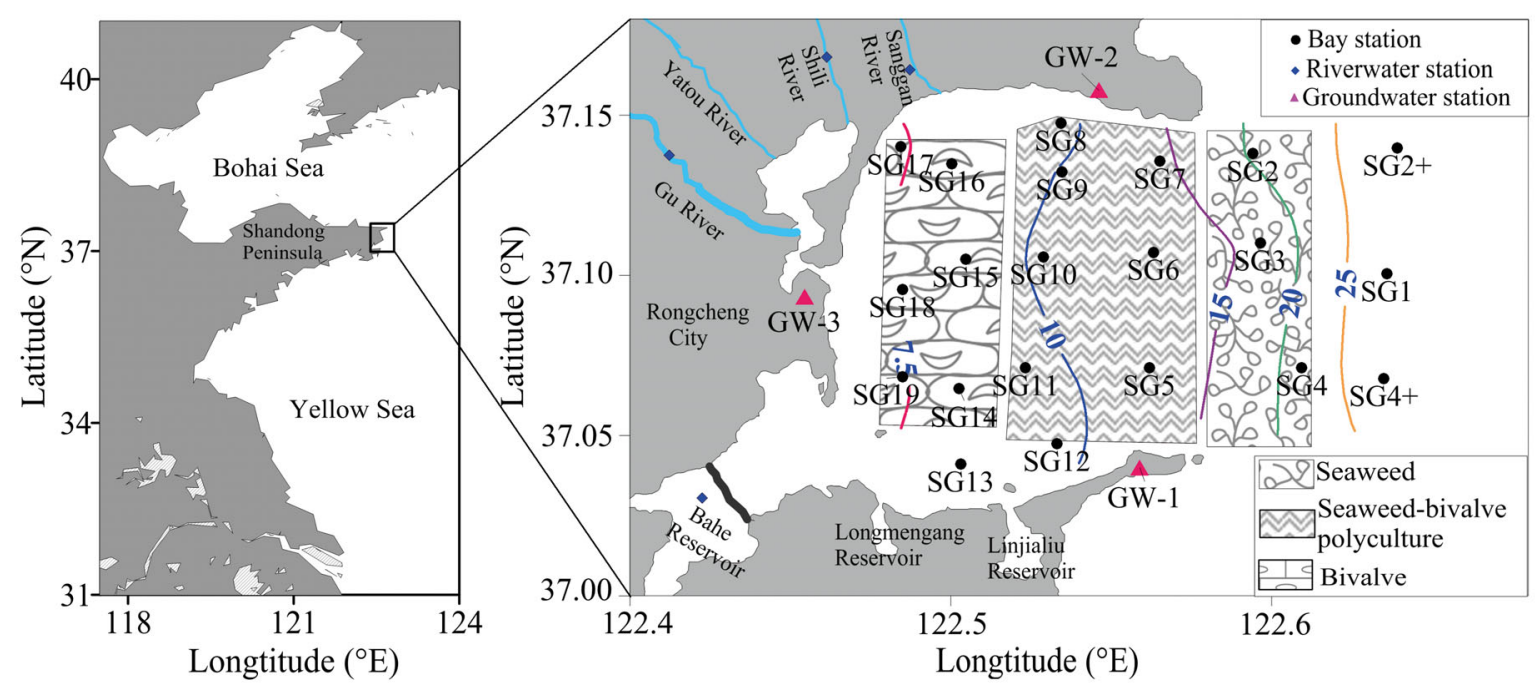

Fig. 1. Locations of field sampling and observation sites in Sanggou Bay in April, July and October 2013

from the sediment cores using 19.21.23F Rhizon CSS soil moisture samplers (Liu et al. 2011) and were frozen until analysis. River water and groundwater sampling was undertaken in April and July 2013 (Fig. 1). On each occasion, a total of 5 river water samples (from the Gu River [2 stations], Shili River, Yatou River, and Bahe Reservoir; Fig. 1) were collected using a 51 clean plastic bucket from relatively fast-moving areas located away from urban regions. Three groundwater samples (from Stns GW-1, GW-2 and GW-3; Fig. 1) were collected from wells along the coastline of Sanggou Bay. Water temperature and salinity were measured in situ using an YSI Professional Plus meter at the time of sample collection. Water samples were filtered in the laboratory within $8 \mathrm{~h}$ of collection through precleaned $0.40 \mu \mathrm{m}$ Nuclepore filters on a class 100 clean bench. The filtrates were placed in acid-cleaned polyethylene bottles and kept frozen until analysis.

Phytoplankton were collected by net tows using a net with a mesh size of $70 \mu \mathrm{m}$ in April 2015. After the trawl, the plankton were filtered through a $200 \mu \mathrm{m}$ mesh to remove the zooplankton and then were stored in plastic bottles previously decontaminated with dilute $\mathrm{HCl}$ solution. These bottles were kept from the sun and heat in an insulated box containing ice throughout the sampling process and transported to the laboratory. Phytoplankton were collected on the weighed $0.40 \mu \mathrm{m}$ Nuclepore filters and freeze dried until analysis. Kelp, G. lemaneiformis, scallops and oysters samples were also collected in the bay during April, July, July and October 2013, respectively, stored in zip-closure plastic bags and kept in an insulated box containing ice throughout the sampling process. The seaweeds were washed with distilled water to remove salts and small invertebrates and freeze dried. The muscle was collected from bivalves and freeze dried. Dried samples were ground into powder to pass through an 80 mesh $(180 \mu \mathrm{m})$ sieve before analysis.

\section{Analytical methods}

Measurement of dissolved selenium concentrations

The analytical techniques for Se(IV) and Se(VI) by hydride generation combined with sector field inductively coupled plasma mass spectrometry (HGICP-MS) (Element $2^{\mathrm{TM}}$ ICP-MS, Thermol) have been described elsewhere (Zhang \& Combs 1996, Chang et al. 2014). Briefly, Se(IV) at an acidity of $2 \mathrm{~mol} \mathrm{l}^{-1} \mathrm{HCl}$ was reacted with $\mathrm{NaBH}_{4}$ to produce hydrogen selenide and was then quantified using HG-ICP-MS. $\mathrm{Se}(\mathrm{VI})$ was quantitatively reduced to $\mathrm{Se}(\mathrm{IV})$ by heating a sample acidified with $3 \mathrm{~mol}^{-1} \mathrm{HCl}$ to $97^{\circ} \mathrm{C}$ for $75 \mathrm{~min}$, then quickly cooling the sample to room temperature using an ice-water bath, and finally following the steps for Se(IV) determination to yield the concentration of dissolved inorganic selenium (DISe). The reduction recovery ranged from 95 to $103 \%$. This reduction method avoided the problematic variation in $\mathrm{Se}(\mathrm{VI})$ reduction behavior with different matrices, and kept the reduction rate at nearly $100 \%$ for a longer period of time than previous methods (e.g. Cutter et al. 1978, Yao \& Zhang 2003). The Se(VI) concentration was calculated as the difference between DISe and Se(IV). The detection limits for Se(IV) and $\mathrm{Se}(\mathrm{VI})$ were 0.025 and $0.030 \mathrm{nmol} \mathrm{l}^{-1}$, respectively. The measurement precisions for Se(IV) and Se(VI) in 
river water were 3.4 and $3.9 \%$, respectively, and those in seawater were 3.1 and $3.4 \%$, respectively. The spiked standard Se(IV) or Se(VI) recovery ranged from 97 to $103 \%$. The accuracy of the methods was tested with standard solutions, Se(IV) 50031-94 and Se(VI) GBW10032, and showed differences within -3.0 and $0.7 \%$, respectively. The concentration of chlorophyll a (chl a) was measured using an ACLWRS chlorophyll turbidity temperature sensor.

Measurement of selenium content of biological tissues

For total selenium content determination, complete digestion of the biological species tissues was performed with a microwave digestion system (MARSXpress, CEM). Samples (about $0.2 \mathrm{~g}$ ) of dry tissue were soaked in $6 \mathrm{ml}$ concentrated $\mathrm{HNO}_{3}$. The digestion program was as follows: the sample was heated to $100^{\circ} \mathrm{C}$ for $10 \mathrm{~min}$, held for $5 \mathrm{~min}$, and then heated to $150^{\circ} \mathrm{C}$ for $5 \mathrm{~min}$, held for $5 \mathrm{~min}$, and finally heated to $180^{\circ} \mathrm{C}$ within $5 \mathrm{~min}$ and held for $45 \mathrm{~min}$. After cooling, the solution was evaporated at $150^{\circ} \mathrm{C}$ to dryness using a heating block within about $2.5 \mathrm{~h}$. Subsequently, the residue was dissolved in $5 \mathrm{ml} 4 \mathrm{~mol} \mathrm{l}^{-1} \mathrm{HCl}_{\text {, and }}$ heated in $110^{\circ} \mathrm{C}$ using the heating block to reduce $\mathrm{Se}(\mathrm{VI})$ to $\mathrm{Se}(\mathrm{IV})$ for $45 \mathrm{~min}$. After cooling, samples were added $15 \mathrm{ml} \mathrm{H}_{2} \mathrm{O}$ and diluted with $1 \mathrm{~mol} \mathrm{l}^{-1} \mathrm{HCl}$ to $50.0 \mathrm{ml}$ in volumetric flask. The selenium concentration was determined by HG-ICP-MS. The biological standard reference materials GBW010024 (sea scallop), GBW010025 (spiral algae) and GBW010050 (prawn) were measured, with results of $1.49 \pm 0.05$, $0.23 \pm 0.008$ and $5.12 \pm 0.05 \mu g^{-1}(2 \sigma, \mathrm{n}=6)$, respectively, with relative error $-0.6,+3.8$, and $+0.3 \%$, respectively, confirming the accuracy of the method.

\section{Data statistics and analysis}

The statistics software package Statistical Package for the Social Sciences version 16.0 (SPSS) was used for all data analyses. Differences were tested for significance using 1-way and 2-way analysis of variance (ANOVA), and $\mathrm{p}<0.05$ was taken to indicate significant difference. Mean values are presented with standard deviation throughout.

\section{Flux estimates}

A steady-state box model based on the Land-Ocean Interactions in the Coastal Zone (LOICZ) Biogeo- chemical Modeling Guidelines was used to construct a DISe budget for Sanggou Bay from water budgets and non-conservative distribution of DISe, which were in turn constrained by the salt balance under steadystate conditions (Gordon et al. 1996).

The vertical diffusional flux of dissolved selenium from the bottom sediment was estimated using a modified form of Fick's first law (Meseck \& Cutter 2012):

$$
J=\theta^{m} D_{o}\left(\frac{\Delta S e}{\Delta z}\right)
$$

where $J$ is the diffusional flux, $\theta$ is the porosity, $m$ has a value of 3 for surface sediments (Ullman \& Aller $1982), D_{0}$ is the effective diffusion coefficient $(-4.87 \times$ $10^{10} \mathrm{~m}^{2} \mathrm{~s}^{-1}$ ) (Meseck \& Cutter 2012), and $\Delta S e / \Delta z$ is the observed concentration gradient of porewater selenium. The selenium concentration at $z=0 \mathrm{~m}\left(\mathrm{Se}_{0}\right)$ in water from the near-bottom of the core was used as the initial point in the concentration gradient. A negative value of $J$ indicates that dissolved selenium is fluxing out of the sediments, while a positive $J$ results from dissolved selenium fluxing into the sediments. The value of $\theta$ in Sanggou Bay was 0.7 (Ning et al. 2016, this Theme Section).

\section{RESULTS}

\section{Hydrographic properties in Sanggou Bay}

The water temperature in the Sanggou Bay displayed a significant horizontal gradient, decreasing from the coast to offshore in spring and summer, with a reversed gradient occurring in autumn (Fig. 2a-c). Mean water temperatures ranged from 7.7 to $20.7^{\circ} \mathrm{C}$ between seasons, reflecting a remarkable seasonal variation (Table 1). The salinity increased from the coast to offshore (Fig. 2d-f) as a result of water exchange with the Yellow Sea. The mean salinity varied slightly, from 28.3 to 31.4 , with lows in July and October due to rainfall and freshwater discharge (Table 1). The average concentrations of phytoplankton biomass, measured as chl $a$, varied between $0.83 \mu \mathrm{g} \mathrm{l}^{-1}$ in spring and autumn, and $6.9 \mu \mathrm{g} \mathrm{l}^{-1}$ in summer (Table 1).

\section{Seasonal variations of inorganic selenium species}

Concentrations of DISe ranged from 0.21 to $1.36 \mathrm{nmol}$ $\mathrm{l}^{-1}$ for all surface water samples in the bay, with a mean of $0.69 \mathrm{nmol}^{-1}$ (Table 1). The critical selenium limit in water is classified as $126 \mathrm{nmol} \mathrm{l}^{-1}$ in China, 


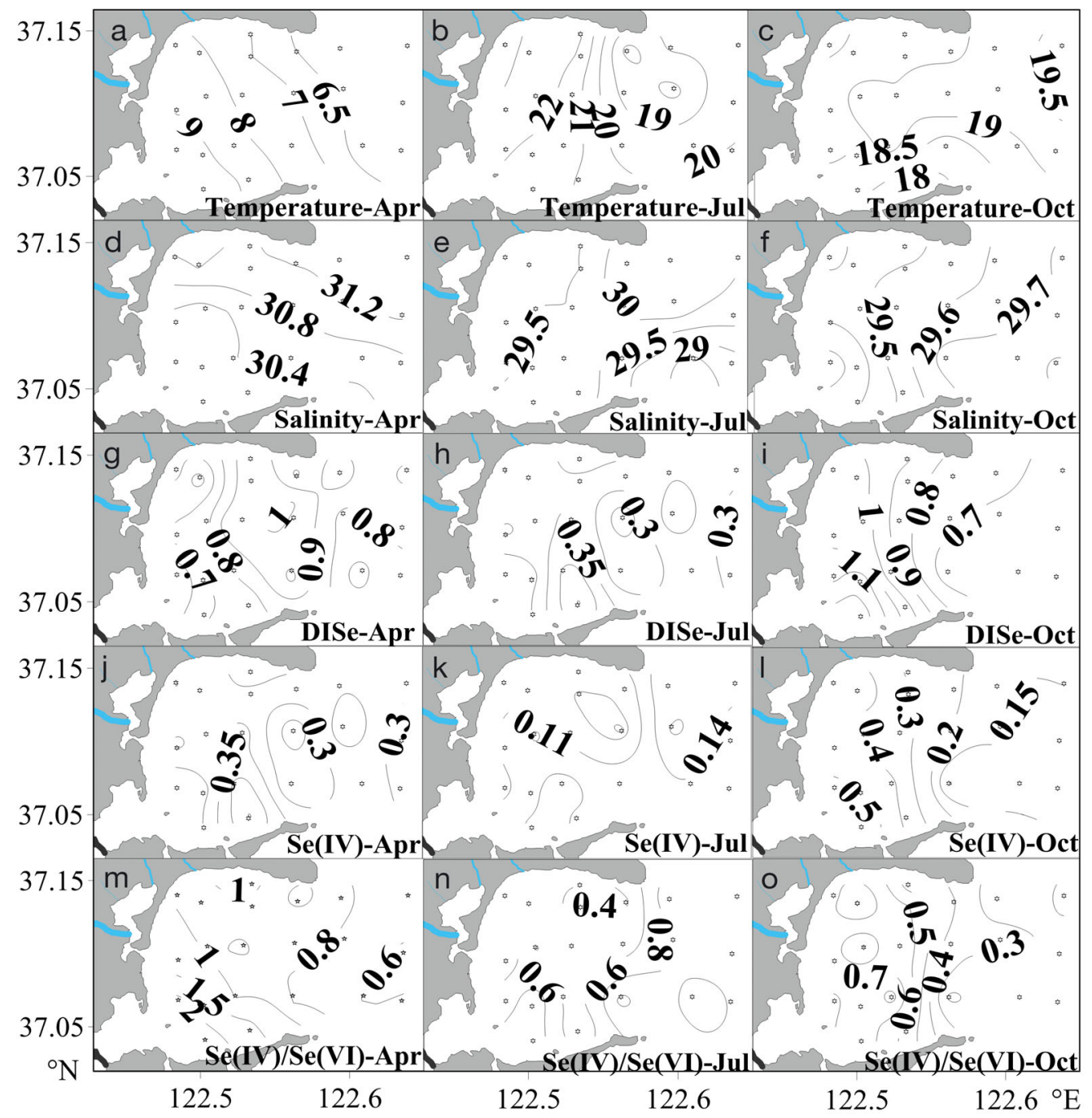

Fig. 2. $(\mathrm{a}-\mathrm{c})$ Temperature, $(\mathrm{d}-\mathrm{f})$ salinity, (g-i) dissolved inorganic selenium (DISe) concentration, (j-l) Se(IV) concentration and $(\mathrm{m}-\mathrm{o}) \mathrm{Se}(\mathrm{IV}) / \mathrm{Se}(\mathrm{VI})$ ratio distributions at the surface of Sanggou Bay in April, July, and October 2013 (left, centre and right columns, respectively)

Table 1. Mean values (with ranges in parentheses) of temperature, salinity, chl $a$, dissolved inorganic selenium (DISe) and Se(IV) concentration and $\mathrm{Se}(\mathrm{IV}) / \mathrm{Se}(\mathrm{VI})$ ratio in the surface water of Sanggou Bay in April, July and October 2013

\begin{tabular}{|lccl|}
\hline & Spring (April) & Summer (July) & Autumn (October) \\
\hline Temperature $\left({ }^{\circ} \mathrm{C}\right)$ & $7.7(6.0-9.9)$ & $20.7(17.7-24.5)$ & $18.5(16.6-19.6)$ \\
Salinity & $30.7(30.1-31.4)$ & $29.6(28.3-30.5)$ & $29.5(29.3-29.8)$ \\
Chl $a\left(\mu \mathrm{l} \mathrm{l}^{-1}\right)$ & $0.83(0.59-2.3)$ & $6.9(0.86-20)$ & $0.83(0.36-2.0)$ \\
DISe $\left(\mathrm{nmol} \mathrm{l}^{-1}\right)$ & $0.79(0.47-1.02)$ & $0.33(0.21-0.46)$ & $0.89(0.61-1.36)$ \\
Se(IV) $\left(\mathrm{nmol} \mathrm{l}^{-1}\right)$ & $0.39(0.24-0.51)$ & $0.12(0.07-0.18)$ & $0.30(0.10-0.58)$ \\
Se(IV)/Se(VI) ratio & $1.07(0.59-2.30)$ & $0.64(0.30-1.06)$ & $0.51(0.18-0.85)$ \\
& & & \\
\hline
\end{tabular}

The minimum mean concentrations of DISe occurred during summer (0.33 nmol $\left.^{-1}\right)$, while the maximum occurred during autumn (0.89 nmol $1^{-1}$ ) (Table 1). The minimum mean concentrations of Se(IV) also occurred during summer $\left(0.12 \mathrm{nmol} \mathrm{l}^{-1}\right)$, but the maximum occurred during spring (0.39 nmol $\mathrm{l}^{-1}$ ) (Table 1). One-way ANOVA showed that the concentrations of DISe and Se(IV) were not significantly different between spring and autumn ( $p>0.05)$, but that the

(State Environmental Protection Administration of China 2002); the dissolved selenium in Sanggou Bay remained 2 orders of magnitude below toxic levels. values in summer were significantly lower than those in spring and autumn ( $\mathrm{p}<0.0001)$. It is clear from Table 1 that mean concentrations of DISe and Se(IV) 
showed similar seasonal patterns, with low values in summer and high values in spring and autumn. The mean Se(IV)/Se(VI) ratios for spring, summer, and autumn were $1.07,0.64$, and 0.51 , respectively (Table 1). One-way ANOVA showed that the Se(IV)/ $\mathrm{Se}(\mathrm{VI})$ ratio was not significantly different between summer and autumn $(p=0.25)$, whereas values in spring were significantly higher than those in summer and autumn ( $p<0.0001)$. The $\mathrm{Se}(\mathrm{IV}) / \mathrm{Se}(\mathrm{VI})$ ratio indicated that $\mathrm{Se}(\mathrm{VI})$ was the dominant species of inorganic selenium in the bay during summer and autumn, but Se(IV) was the dominant species in the large proportion along the coast of the bay during spring.

\section{Horizontal distributions of inorganic selenium species}

The horizontal distributions of DISe, Se(IV), and the $\mathrm{Se}(\mathrm{IV}) / \mathrm{Se}(\mathrm{VI})$ ratio in surface waters of Sanggou bay show similar features, such as a strong horizontal gradient from the coast to offshore (Fig. 2g-o). The concentrations of DISe along the coast during spring were lower than concentrations in the rest of the bay (Fig. 2g). While DISe showed a strong zonal distribution along the coast during autumn, decreasing offshore from 1.2 to $0.6 \mathrm{nmol} \mathrm{l}^{-1}$, it was rather evenly distributed in summer (Fig. $2 \mathrm{~h}, \mathrm{i}$ ). The distribution of Se(IV) in the bay exhibited a similar pattern to DISe in spring, summer, and autumn (Fig. 2j-l). The $\mathrm{Se}(\mathrm{IV}) / \mathrm{Se}$ (VI) ratio had a zonal distribution along the coast during spring and autumn, decreasing offshore from 2 to 0.6 and 0.7 to 0.3 , respectively (Fig. $2 \mathrm{~m}, \mathrm{o}$ ); however, during summer, the ratio was higher along the coast and at the mouth of the bay (0.8) as compared with in the central region (0.4) (Fig. 2n).
A 2-way ANOVA was conducted that examined the effect of season and space (i.e. S-region, Bregion and SB-region, representing the 3 main types of aquaculture in Sanggou Bay) on Se(IV) and $\mathrm{Se}(\mathrm{VI})$ distribution. Both season and space significantly affected $\mathrm{Se}(\mathrm{IV})$ and $\mathrm{Se}(\mathrm{VI})$ concentrations $(p=0.0001)$. There was also significant interaction between season and space ( $p=0.0001)$. Se(IV) concentrations in the S-region and B-region were significantly less than those in the SB-region in spring ( $p=0.046)$ (Fig. 3a). In contrast, Se(VI) concentrations during spring in the B-region were significantly lower than those in the S-region and SB-region $(\mathrm{p}=$ 0.007) (Fig. 3b). During summer, Se(IV) concentrations in the S-region were slightly higher than those in the SB-region and B-region $(\mathrm{p}=0.015)$ (Fig. 3a). There was no significant difference in $\mathrm{Se}(\mathrm{VI})$ concentrations between different regions during summer $(p=0.235)$. In autumn, Se(IV) concentrations in the bay increased in the following order: S-region, SB-region and B-region ( $\mathrm{p}<0.0001)$ (Fig. 3a). Se(VI) concentrations shared the same pattern $(p<0.02)$, with low values in the S-region and high values in the B-region (Fig. 3b).

\section{Riverine input of selenium to Sanggou Bay}

As shown in Table 2, the DISe and Se(IV) concentrations in 4 riverine waters were not significantly different between spring and summer $(p>0.2)$. Overall, DISe concentrations in riverine water ranged from 0.69 to $1.5 \mathrm{nmol} \mathrm{l}^{-1}$ with a mean of $1.0 \mathrm{nmol} \mathrm{l}^{-1}$; these were slightly higher than those observed in the water column in Sanggou Bay $\left(0.68 \pm 0.29 \mathrm{nmol} \mathrm{l}^{-1}\right)$ during this study (Tables $1 \& 2$ ). The mean concentration of Se(IV) was $0.14 \mathrm{nmol} \mathrm{l}^{-1}$ in both spring and
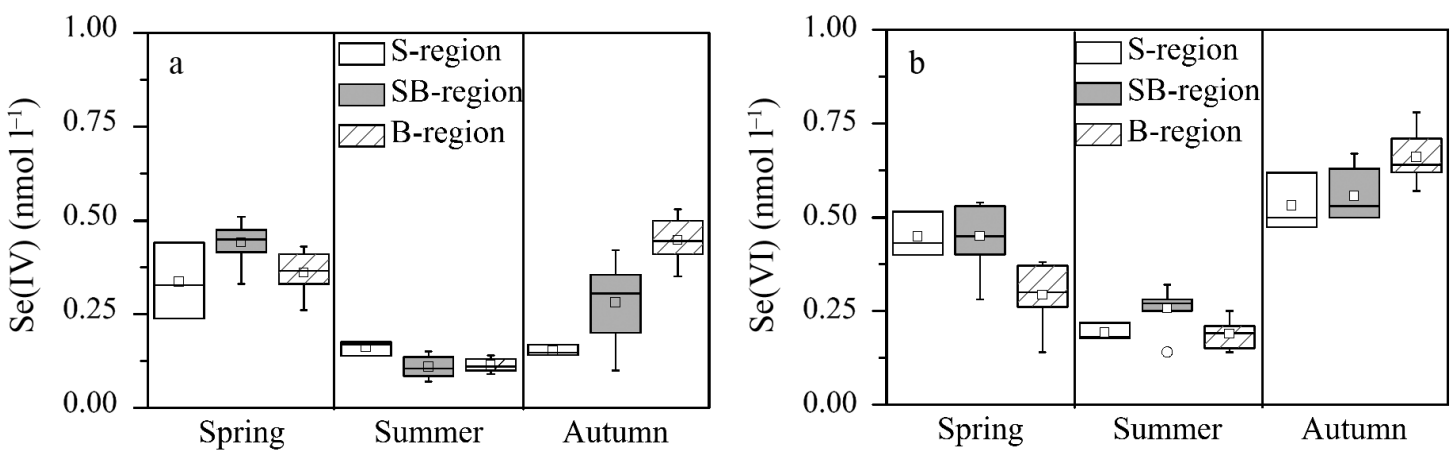

Fig. 3. Box plots of (a) Se(IV) and (b) Se(VI) concentrations in seaweed monoculture (S-region), seaweed-bivalve polyculture (SB-region) and bivalve monoculture (B-region) in spring, summer and autumn of 2013. The ends of the box and the ends of the whiskers, and the line across the box represent the 25 th and 75 th percentiles, the 1st and 99th percentiles and the median, respectively; the open square inside the box indicates the mean value. A circle represents an outlier 
Table 2. Concentrations of dissolved inorganic selenium (DISe) and Se(IV) and $\mathrm{Se}(\mathrm{IV}) / \mathrm{Se}(\mathrm{VI})$ ratio in major rivers that enter into Sanggou Bay and in groundwater (GW) along the coastline of Sanggou Bay, measured in April and July 2013

\begin{tabular}{|llccc|}
\hline Water source & $\begin{array}{l}\text { Sampling location / } \\
\text { station number }\end{array}$ & $\begin{array}{c}\text { DISe } \\
\left(\mathrm{nmol} \mathrm{l}^{-1}\right)\end{array}$ & $\begin{array}{c}\text { Se(IV) } \\
\left(\mathrm{nmol} \mathrm{l}^{-1}\right)\end{array}$ & $\begin{array}{c}\text { Se(IV)/Se(VI) } \\
\text { ratio }\end{array}$ \\
\hline Spring (April 2013) & & & \\
River & Gu River & 1.21 & 0.18 & 0.17 \\
& Sanggan River & 0.69 & 0.17 & 0.21 \\
& Shili River & 1.12 & 0.08 & 0.18 \\
Bahe Reservoir & 0.91 & 0.12 & 0.10 \\
Groundwater & GW-1 & 34.9 & 1.36 & 0.04 \\
& GW-2 & 3.14 & 0.60 & 0.24 \\
GW-3 & 3.49 & 0.26 & 0.08 \\
River & GWmer (July 2013) & & & \\
& Gu River & 1.49 & 0.11 & 0.08 \\
Sanggan River & 0.84 & 0.21 & 0.18 \\
Groundwater & Shili River & 1.03 & 0.12 & 0.25 \\
& Bahe Reservoir & 1.16 & 0.13 & 0.11 \\
& GW-1 & 27.5 & 2.76 & 0.11 \\
& GW-2 & 5.45 & 0.49 & 0.10 \\
& GW-3 & 3.54 & 0.89 & 0.34 \\
\hline
\end{tabular}

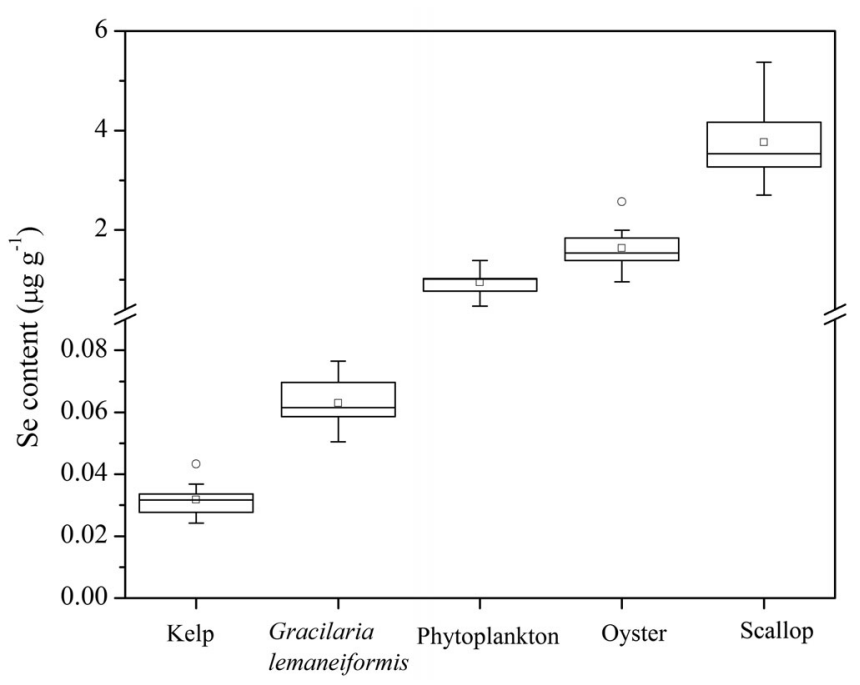

Fig. 4. Selenium (Se) content in kelp $(\mathrm{n}=11)$, G. lemaneiformis $(\mathrm{n}=9)$, phytoplankton $(\mathrm{n}=6)$, oysters $(\mathrm{n}=9)$ and scallops $(n=9)$. Box plot details as in Fig. 3

summer; this concentration was comparable to the one observed in the water column in Sanggou Bay during summer, but was lower than those observed during spring and autumn (Tables $1 \& 2$ ). The mean $\mathrm{Se}(\mathrm{IV}) / \mathrm{Se}(\mathrm{VI})$ ratio was 0.16 , with a range of 0.08 to 0.25 , indicating that $\mathrm{Se}(\mathrm{VI})$ was the major inorganic species in riverine water. The DISe concentrations in the Sanggan River during spring and summer were lower than those in the Gu River, the Shili River and Bahe Reservoir; however, concentrations of DISe and Se(IV) varied only slightly among rivers.

\section{Groundwater input of selenium to Sanggou Bay}

The salinity values of groundwater samples were $<0.1$, indicating that they are freshwater. The DISe and Se(IV) concentrations in groundwater showed little temporal variation and were not significantly different between spring and summer $(p>0.1)$. DISe was $>25 \mathrm{nmol} \mathrm{l}^{-1}$ in the sample from Stn GW-1, while it was $<6 \mathrm{nmol}$ $1^{-1}$ in samples from Stns GW-2 and GW-3 (Table 2). The low concentrations of ${ }^{226}$ Ra in sample GW-1 (Wang et al. 2014) indicates the low activity of rock-water interactions. Moreover, the dissolved inorganic arsenic concentration was nearly 10 times higher in sample GW-1 than samples GW-2 and GW-3 (Li et al. 2014). Stn GW-1 was excluded from the calculation of average selenium concentration. The mean DISe and Se(IV) concentrations were $3.91 \pm 1.05 \mathrm{nmol} \mathrm{l}^{-1}$ and $0.56 \pm 0.26 \mathrm{nmol}$ $1^{-1}$, respectively. The mean $\mathrm{Se}(\mathrm{IV}) / \mathrm{Se}(\mathrm{VI})$ ratio was 0.15, indicating that $\mathrm{Se}(\mathrm{VI})$ was the predominant species in the groundwater. The mean DISe concentration in groundwater (3.91 nmol $\mathrm{l}^{-1}$ ) was nearly 4 times higher than that in riverine water $\left(1.0 \mathrm{nmol}^{-1}\right)$. Compared with surface water, groundwater usually contains higher content due to greater contact time for rock-water interactions (Fordyce 2013).

\section{Selenium content in aquaculture species}

The lowest content of Se was present in kelps $\left(0.032 \pm 0.005 \mathrm{ug} \mathrm{g}^{-1}\right)$, followed by $G$. lemaneiformis $\left(0.063 \pm 0.008 \mu \mathrm{g} \mathrm{g}^{-1}\right)$ (Fig. 4) these values were in the range of selenium content (0.01 to $0.6 \mu \mathrm{g} \mathrm{g}^{-1}$ ) reported elsewhere in seaweed (Liu et al. 1987, Maher et al. 1992, Barwick \& Maher 2003). These seaweeds accumulated selenium to concentrations 3 to 4 orders of magnitude above the ambient concentration in the seawater. The Se content for phytoplankton $\left(0.9 \pm 0.3 \mu \mathrm{g} \mathrm{g}^{-1}\right)$ was 10 to 30 times higher than for seaweeds (Fig. 4), and the value was within the range of those previously published for marine phytoplankton (0.5 to $4.5 \mathrm{\mu g} \mathrm{g}^{-1}$ ) (Liu et al. 1987, Baines \& Fisher 2001, Sherrard et al. 2004). The highest mean Se contents were observed in bivalves, i.e. scallops $\left(3.6 \pm 0.7 \mu \mathrm{g} \mathrm{g}^{-1}\right)$ and oysters $\left(1.6 \pm 0.4 \mu \mathrm{g} \mathrm{g}^{-1}\right)$; these values were consistent with 
the range in bivalves reported elsewhere $(0.24$ to $4.6 \mathrm{\mu g} \mathrm{g}^{-1}$ ) (Liu et al. 1987, Baldwin \& Maher 1997, He \& Wang 2013).

\section{DISCUSSION}

\section{Influence of phytoplankton on selenium distribution}

As shown in Table 1, Se(IV) concentrations were lower in summer and higher in spring, while the opposite was true for chl a concentrations. Studies have indicated that Se(IV) and Se(VI) can both be assimilated by phytoplankton, with Se(IV) being the preferred species for phytoplankton uptake (Apte et al. 1986, Vandermeulen \& Foda 1988, Baines \& Fisher 2001). Moreover, as illustrated in Fig. 2m,o, $\mathrm{Se}(\mathrm{IV}) / \mathrm{Se}(\mathrm{VI})$ ratios along the coast decreased towards offshore. In the coastal regions of the bay, the ratio was $>0.5$ during all 3 seasons, while the ratio in the freshwater end member (river and groundwater) was normally <0.2 (Table 2). There has been a paucity of investigations on selenium species in the Yellow Sea; the mean Se(IV)/Se(VI) ratio for Bohai Sea is 0.45 (Yao \& Zhang 2005) and the value for East China Sea was 0.32 (Y. Chang et al. unpubl.). The relatively high $\mathrm{Se}(\mathrm{IV}) / \mathrm{Se}(\mathrm{VI})$ ratios in the bay compared to rivers and surrounding marine basins suggest that either Se(IV) is produced or Se(VI) is preferentially consumed in the bay. Both anions can be assimilated into biomass, but phytoplankton usually has a higher affinity for Se(IV) than for Se(VI) (Fig. 5). Therefore, preferential uptake of Se(VI)

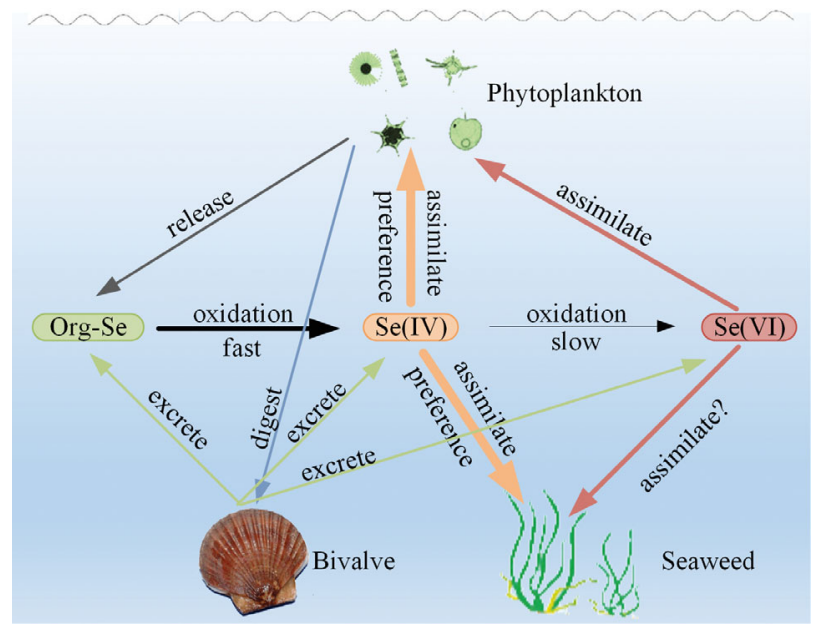

Fig. 5. A conceptual diagram of the biological effects of phytoplankton, seaweed and bivalves on selenium speciation (based on Vandermeulen \& Foda 1988, Besser et al. 1994, Hu et al. 1997, Baines \& Fisher 2001, present study) probably cannot explain the observed pattern. However, the organic selenium is later released into the water column where it oxidizes to Se(IV) (Cutter \& Bruland 1984), as dissolved oxygen is high in the bay. In contrast, the rate constant of the oxidation from $\mathrm{Se}(\mathrm{IV})$ to $\mathrm{Se}(\mathrm{VI})$ was $8.7 \times 10^{-4} \mathrm{yr}^{-1}$, which means it takes $>1000$ yr to oxidize Se(IV) to Se(VI) (Cutter \& Bruland 1984); therefore, this process can be ignored. This may also be the reason why $\mathrm{Se}(\mathrm{IV}) / \mathrm{Se}(\mathrm{VI})$ ratios are elevated at the mouth of the bay during summer, as large amounts of algae would release organic selenium, which would then be oxidized to Se(IV) (Fig. 2n)

\section{Influence of mariculture species on selenium distribution}

The distribution of selenium was greatly affected by the mariculture species, as shown in Fig. 3. Laboratory studies have indicated that both $\mathrm{Se}(\mathrm{IV})$ and $\mathrm{Se}(\mathrm{VI})$ can increase the growth of macroalgae, with $\mathrm{Se}(\mathrm{IV})$ taken up more readily than Se(VI) (Fries 1982, Horne 1991). Kelp can bioaccumulate $>50$ times more inorganic selenium in a Se(IV) enriched culture medium than in seawater (Yan et al. 2004). The kelp in the bay is generally cultivated in November and is harvested in late May. Thus, due to the fast growth of kelp, Se(IV) would be preferentially taken up by the seaweed (Fries 1982). This would explain the relatively low concentrations of Se(IV) in the kelp monoculture region (S-region) in spring (Fig. 3a). Utilization of Se(VI) is more limited compared with Se(IV) (Fries 1982), resulting in the high levels of Se(VI) present in the S-region during spring (Fig. 3b). Moreover, the elevated Se(VI) may be caused by the Yellow Sea input. The G. lemaneiformis monoculture is planted after the harvest of kelp in late May. The assimilation of selenium by $G$. lemaneiformis is similar to that of kelp (Fries 1982).

Bivalves mainly accumulate selenium from particulate sources by ingestion and assimilation, while passive uptake from dissolved phases is negligible (Wang \& Fisher 1996, Griscom \& Fisher 2004, Luoma \& Presser 2009). Bivalves have been observed to accumulate ingested selenium to concentrations markedly higher than those present in the algal diet, due to high assimilation rates of cytosolic selenium (Wang \& Fisher 1996, Reinfelder et al. 1997). After ingestion, bivalves excrete selenium as dissolved phases probably in the forms of inorganic selenium, including $\mathrm{Se}(\mathrm{IV})$ and Se(VI), and organic selenium (Wang \& Fisher 1996), and the organic selenium can then be 
oxidized to Se(IV) (Cutter \& Bruland 1984). These processes probably resulted in the high Se(IV) and $\mathrm{Se}(\mathrm{VI})$ concentrations in the bivalve monoculture region (B-region) during autumn (Fig. 3a,b). Another possible reason for elevated $\mathrm{Se}(\mathrm{VI})$ concentrations in B-region was the input from river or groundwater.

The intensive kelp and bivalve aquaculture activities occurring over large areas of Sanggou Bay have a significant influence on the distribution of selenium in the bay. A conceptual diagram of the biological effects of phytoplankton, seaweed and bivalves on the selenium species in Sanggou Bay is shown in Fig. 5. Phytoplankton and seaweeds (kelp and G. lemaneiformis) preferentially assimilate Se(IV) and convert it to organic selenium (Fries 1982, Vandermeulen \& Foda 1988, Horne 1991, Besser et al. 1994, Hu et al. 1997, Baines \& Fisher 2001). Dissolved organic selenium regenerated from biogenic particles (as phytoplankton cells die and/or bivalves excrete) is quickly oxidized to Se(IV) in the oxygenated water (Cutter \& Bruland 1984, Wang \& Fisher 1996, Luoma \& Presser 2009). However, neither Se(IV) nor organic selenium are reconverted to $\mathrm{Se}(\mathrm{VI})$, as these reactions have a half reaction time of hundreds of years (Cutter \& Bruland 1984). Thus, the seaweeds assimilate both $\mathrm{Se}(\mathrm{IV})$ and $\mathrm{Se}(\mathrm{VI})$, resulting in low levels in the water column, while the bivalves assimilate particulate selenium but excrete dissolved selenium, replenishing selenium levels in the water column.

\section{DISe budget for Sanggou Bay}

Inputs of selenium to Sanggou Bay

The riverine input of DISe into Sanggou Bay $\left(Y_{\mathrm{Q}}\right)$ can reach $15 \pm 4 \mathrm{~kg} \mathrm{yr}^{-1}$ (see Fig. 6) by multiplying the mean DISe concentrations with the annual mean river water discharge.

The submarine groundwater discharge into the bay during summer is (9.45 to 11.20$) \times 10^{9} \mathrm{~m}^{3} \mathrm{yr}^{-1}$, as determined by calculation based on the nonconservative inventory of ${ }^{226} \mathrm{Ra}$ and ${ }^{228} \mathrm{Ra}$ (Wang et al. 2014). As submarine groundwater discharge includes recycled seawater (75 to $90 \%$ ) as well as fresh groundwater (Moore 1996), the hypothesis of groundwater discharge over the whole bay-instead of just along the shoreline-overestimates the discharge volume. Therefore, we assumed that $5 \%$ of the submarine groundwater discharge represented a best estimate of the fresh groundwater discharge, resulting in a value of $0.47 \times 10^{9} \mathrm{~m}^{3} \mathrm{yr}^{-1}$. The annual input of DISe from fresh groundwater $\left(Y_{\mathrm{G}}\right)$ into the bay was then estimated by multiplying the mean DISe concentrations of groundwater and annual fresh groundwater discharge, giving a value of $146 \pm$ $39 \mathrm{~kg} \mathrm{yr}^{-1}$.

The diffusional flux of DISe from the sediment was calculated for the bay using Eq. (1). The DISe concentrations in near-bottom water and porewater for Stn SG5 were $0.32 \mathrm{nmol} \mathrm{l}^{-1}$ and $0.45 \mathrm{nmol} \mathrm{l}^{-1}$, respectively, and DISe concentrations in near-bottom water and porewater for Stn SG6 were 0.3 and $0.41 \mathrm{nmol}$ $\mathrm{l}^{-1}$, respectively. Calculations demonstrate that there can be a -0.68 and a $-0.58 \mathrm{nmol} \mathrm{m}^{-2} \mathrm{yr}^{-1}$ flux of DISe between the sediment and water column at Stns SG5 and SG6, respectively. The negative values indicate flux of DISe out of the sediment. The diffusional flux from the sediment to the water column in the bay was estimated by averaging the diffusional flux from each of the different regions. The DISe flux from the sediments $\left(Y_{\mathrm{S}}\right)$ was $(7.2 \pm 0.8) \times 10^{-3} \mathrm{~kg} \mathrm{yr}^{-1}$.

The selenium concentration in rainwater ranges from 1.3 to $2.6 \mathrm{nmol} \mathrm{l}^{-1}$ in China (Zhu \& Tan 1988). A rainwater sample was collected during summer in the Bay with a selenium concentration of $1.7 \mathrm{nmol} \mathrm{l}^{-1}$, which is within the range of rainwater values in China (Zhu \& Tan 1988). Thus, the annual wet deposition of DISe was estimated to be $17.5 \mathrm{~kg} \mathrm{yr}^{-1}$, by multiplying the selenium concentration in rainwater with the amount of annual rainfall. The amount of selenium in dry deposition is not known for this

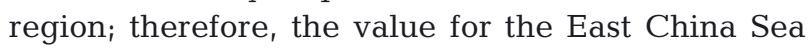
(soluble dry deposition of $0.27 \pm 0.48 \mu \mathrm{g} \mathrm{m}^{-2} \mathrm{~d}^{-1}$ ) (Hsu et al. 2010) has been adopted to estimate the annual dry deposition of selenium into the bay. Accordingly, the total atmospheric input (wet and dry deposition) of selenium into the bay $\left(Y_{\mathrm{P}}\right)$ was $32 \pm 25 \mathrm{~kg} \mathrm{yr}^{-1}$.

\section{Biological utilization of selenium}

The elemental Se:C ratio for phytoplankton in seawater was $(8.5 \pm 3.0) \times 10^{-6}$, which were within the range of those previously pubished for marine phytoplankton (Liu et al. 1987, Baines \& Fisher 2001, Sherrard et al. 2004), and the carbon fixed by phytoplankton in Sanggou Bay is $9.5 \times 10^{6} \mathrm{~kg} \mathrm{yr}^{-1}$ (Jiang et al. 2015). Utilization of selenium by phytoplankton in Sanggou Bay was estimated to be $-81 \pm 29 \mathrm{~kg} \mathrm{yr}^{-1}$ (negative values indicate removal of selenium from the bay through assimilation by biological organisms; see Fig. 6) by multiplying the carbon fixed by phytoplankton and the elemental Se/C ratio for phytoplankton in Sanggou Bay. 
Intensive aquaculture activities have a large influence on selenium levels in Sanggou Bay. The amount of selenium removed from the bay by aquaculture activities was calculated by multiplying aquacultural production in the bay (Rongcheng Fisheries Technology Extension Station 2012) and the selenium content in the cultured species, including kelp, $G$. lemaneiformis, scallops, and oysters. Thus, the amount of selenium fixed by kelp, G. lemaneiformis, scallops and oysters was $2.7 \pm 0.4,1.6 \pm 0.2,54 \pm 11$, and $98 \pm 54 \mathrm{~kg} \mathrm{yr}^{-1}$, respectively. The highest selenium utilization was by scallops and oysters (151 \pm 30 $\left.\mathrm{kg} \mathrm{yr}^{-1}\right)$, followed by phytoplankton $\left(81 \pm 29 \mathrm{~kg} \mathrm{yr}^{-1}\right)$ and seaweed $\left(4.31 \pm 0.5 \mathrm{~kg} \mathrm{yr}^{-1}\right)$, and the total selenium utilization was estimated to be about $236 \pm 42$ $\mathrm{kg} \mathrm{yr}^{-1}$ (see Fig. 6).

\section{Selenium budget for Sanggou Bay}

The steady-state box model, illustrated in Fig. 6, calculates the water and salt budgets, and then estimates the mass balance of DISe in Sanggou Bay, including exchange with the Yellow Sea. Freshwater inputs from river discharge $\left(V_{\mathrm{Q}}\right)$, groundwater discharge $\left(V_{\mathrm{G}}\right)$ and precipitation $\left(V_{\mathrm{P}}\right)$ are $0.19 \times 10^{9}$ (Editorial Board of Annals of Bays in China 1991), $0.47 \times 10^{9}$

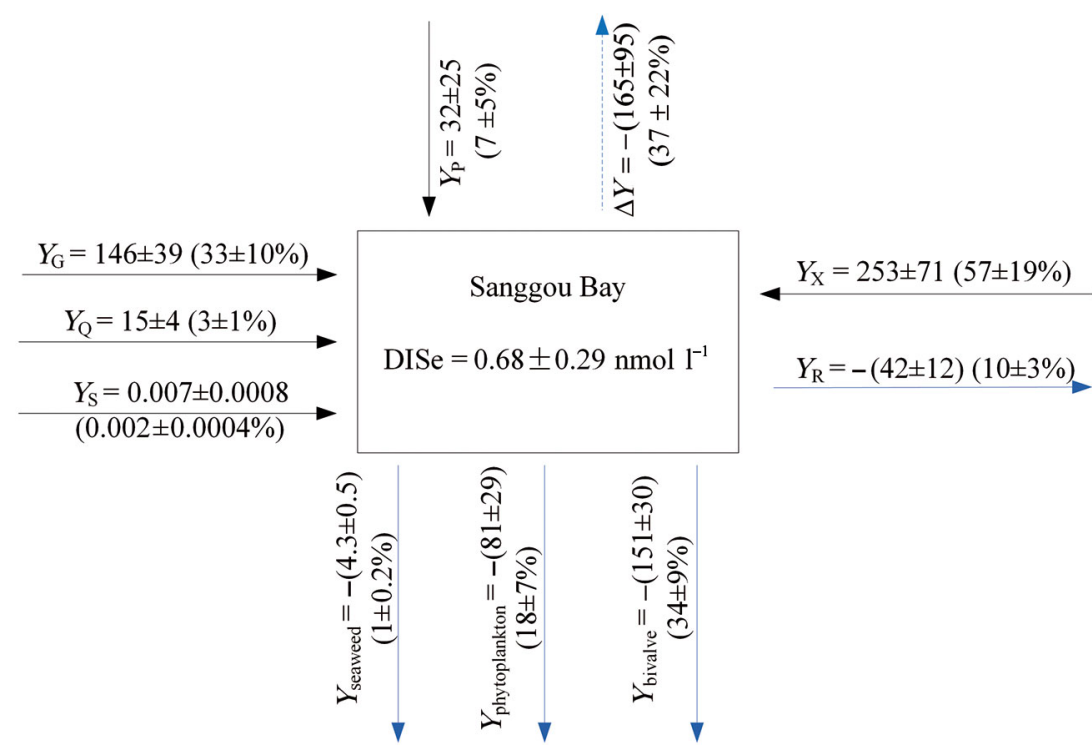

Fig. 6. Selenium budget in Sanggou Bay, showing inputs and outputs $(Y)$ as absolute values $\left(\mathrm{kg} \mathrm{yr}^{-1}\right.$; mean $\left.\pm \mathrm{SD}\right)$ and as percentages of total input. Positive values of $Y$ indicate transport into Sanggou Bay; negative values indicate export of dissolved inorganic selenium (DISe) from Sanggou Bay or assimilation by biological organisms. $Y_{\mathrm{P}}$ : atmospheric deposition; $Y_{\mathrm{Q}}$ : riverine input; $Y_{\mathrm{G}}$ : groundwater input; $Y_{\mathrm{X}}$ : exchange between Sanggou Bay and Yellow Sea; $Y_{R}$ : net transport from Yellow Sea to Sanggou Bay; $Y_{\mathrm{S}}$ : sediment/diffusion; $\Delta Y$ : net internal sink
(Wang et al. 2014) and $0.13 \times 10^{9} \mathrm{~m}^{3} \mathrm{yr}^{-1}$ (Shandong province Rongcheng City the Local Chronicles Compilation Committee 1999), respectively. These inputs are reduced by evaporation $\left(V_{\mathrm{E}}\right)$, which is $0.15 \times$ $10^{9} \mathrm{~m}^{3} \mathrm{yr}^{-1}$ (Shandong province Rongcheng City the Local Chronicles Compilation Committee 1999). From the water mass balance, net water exchange $\left(V_{R}\right)$ is from Sanggou Bay to the Yellow Sea, with a residual flow of $-0.64 \times 10^{9} \mathrm{~m}^{3} \mathrm{yr}^{-1}$ (positive values indicate transport into the bay, negative values export from the bay to the Yellow Sea). Using a salinity of 0 for freshwater input, and salinities of 30 and 32 for Sanggou Bay and the Yellow Sea (Lin et al. 2005), respectively, the water exchange flow from the Yellow Sea to Sanggou Bay $\left(V_{\mathrm{X}}\right)$ is $9.96 \times 10^{9} \mathrm{~m}^{3} \mathrm{yr}^{-1}$, based on the salt balance in the bay. When calculating the net DISe transport from the Yellow Sea to Sanggou Bay, the mean the DISe concentration $\left(1 \pm 0.44 \mathrm{nmol} \mathrm{l}^{-1}\right)$ of Bohai Sea (Yao \& Zhang 2005) and the East China Sea (Y. Chang et al. unpubl. data) was used as the value for the Yellow Sea, where DISe data are lacking. The net transport $\left(Y_{\mathrm{R}}\right)$ from Sanggou Bay to the Yellow Sea is $-42 \pm 12 \mathrm{~kg} \mathrm{yr}^{-1}$ (positive values indicate transport into the bay, negative values export from the bay to the Yellow Sea), and the exchange $\left(Y_{X}\right)$ between the Yellow Sea and Sanggou Bay is $253 \pm 71 \mathrm{~kg} \mathrm{yr}^{-1}$. The data obtained in this study allow for the calculation of selenium budgets in Sanggou Bay (Fig. 6). Atmospheric dry and wet depositions $\left(Y_{\mathrm{P}}\right)$, riverine input $\left(Y_{\mathrm{Q}}\right)$, groundwater influx $\left(Y_{\mathrm{G}}\right)$, exchange between Yellow Sea and Sanggou Bay $\left(Y_{\mathrm{X}}\right)$, net transport from the Yellow Sea to Sanggou Bay $\left(Y_{\mathrm{R}}\right)$, sediment diffusion $\left(Y_{\mathrm{S}}\right)$, and biological fluxes are all shown in Fig. 6. The exchange between Sanggou Bay and the Yellow Sea $\left(Y_{\mathrm{X}}\right)$ was the major source of selenium to Sanggou Bay, contributing $57 \pm 19 \%$ of total DISe inputs. Groundwater discharge $\left(Y_{\mathrm{G}}\right)$ accounted for $33 \pm 10 \%$ of the total DISe input, making it the second largest source of selenium into the bay. However, the exchange of DISe flux $(0.002 \pm 0.0004 \%)$ between the sediment and the water column was negligible compared with other sources. The sediment-water exchange of selenium is also a negligible source in San Francisco Bay, as indicated by stable isotope ratios (Johnson et al. 2000) and sediment porewater values (Meseck \& Cutter 2012). The net transport of DISe from Sanggou Bay to the Yellow Sea accounted for $10 \pm 3 \%$ of the DISe export. 
The amount of selenium utilized by bivalves was $151 \pm 30 \mathrm{~kg} \mathrm{yr}^{-1}$. This amount was $34 \pm 9 \%$ of the total DISe input (Fig. 6), making bivalves the most important selenium sink. Phytoplankton assimilation was another sink of selenium, using $18 \pm 7 \%$ of the total DISe input, while the seaweed assimilated only $1 \pm 0.2 \%$ of the total DISe input (Fig. 6). Thus, biological activity removed nearly $53 \pm$ $12 \%$ of the DISe out of the water column and was the major sink of DISe in Sanggou Bay. This means with the harvesting of marine products, nearly half of the selenium was removed out of the bay.

The input of DISe was $445 \pm 85 \mathrm{~kg} \mathrm{yr}^{-1}$, and output of DISe was $280 \pm 42 \mathrm{~kg} \mathrm{yr}^{-1}$ in the bay. There was a net imbalance between the input and output of dissolved selenium, however. The selenium budgets in Sanggou Bay are only approximations, which depend on the accuracy of the freshwater, water exchange fluxes between Sanggou Bay and the Yellow Sea. If these flux estimates are valid, however, there is a net internal sink of -165 $\pm 95 \mathrm{~kg} \mathrm{yr}^{-1}(37 \pm 22 \%)$ in the bay (Fig. 6). Studies have shown that algae can form dimethylselenide and dimethyldiselenide, which can be volatilized and released into the atmosphere (Ansede \& Yoch 1997). The selenium flux of dimethylselenide to the atmosphere was estimated to be 60 to $260 \mathrm{~kg} \mathrm{yr}^{-1}$ in Gironde Estuary (Ansede \& Yoch 1997), and methylation was estimated to account for 10 to $30 \%$ of the selenium removed from San Francisco Bay (Hansen et al. 1998). Thus, internal sinks of DISe in Sanggou Bay might include emission from the water column into the atmosphere as volatile selenium, dissimilatory reduction of $\mathrm{Se}(\mathrm{VI})$ and $\mathrm{Se}(\mathrm{IV})$ to inorganic reduced phases (Se0, Se-II) (Stüeken et al. 2015), and/or transformation to other organic and particulate forms of selenium. To better constrain the uncertainty of budget calculations, more observations are required to understand the biogeochemical process of selenium in Sanggou Bay.

\section{Sensitivity analysis}

Box model sensitivity analysis were exampled by changing model parameters by $10 \%$ in order to evaluate model response. The sensitivity was quantified by calculating a normalized sensitivity defined as the percentage change in a variable produced by a percentage change in the parameter. able 3. Normalized parameter sensitivity of the net internal sink of dissolved inorganic selenium (DISe) $(\Delta Y)$ for each parameter

\begin{tabular}{lcc} 
Parameter & $\begin{array}{c}\text { Treatment } \\
(\%)\end{array}$ & $\begin{array}{c}\text { Normalized } \\
\text { sensitivity }(\%)\end{array}$ \\
\hline River discharge $\left(V_{\mathrm{Q}}\right)$ & 10 & 4.7 \\
Groundwater discharge $\left(V_{\mathrm{G}}\right)$ & 10 & 18 \\
Precipitation $\left(V_{\mathrm{P}}\right)$ & 10 & 3.6 \\
Evaporation $\left(V_{\mathrm{E}}\right)$ & 10 & -3.0 \\
DISe concentration in Yellow Sea & 10 & 47 \\
DISe concentration in Sanggou Bay & 10 & -33 \\
DISe concentration in rivers & 10 & 0.9 \\
DISe concentration in groundwater & 10 & 8.8 \\
DISe concentration in rainwater & 10 & 1.1 \\
Soluble dry deposition & 10 & 0.9 \\
DISe flux in sediments $\left(Y_{\mathrm{S}}\right)$ & 10 & 1.1 \\
Se content in phytoplankton & 10 & -4.9 \\
Se content in kelp & 10 & -0.2 \\
Se content in G. lemaneiformis & 10 & -0.1 \\
Se content in oysters & 10 & -5.9 \\
Se content in scallops & 10 & -3.3 \\
Carbon fixed by phytoplankton & 10 & -4.9 \\
Production of kelp & 10 & -0.2 \\
Production of $G$. lemaneiformis & 10 & -0.1 \\
Production of oysters & 10 & -5.9 \\
Production of scallops & 10 & -3.3 \\
\hline
\end{tabular}

Ten percentage changes in parameters of DISe concentration for Yellow Sea, DISe concentration for Sanggou Bay and groundwater discharge result in changes in net internal sink $(\Delta Y)$ yield of $47,-32$ and $18 \%$, respectively, while changes in other parameters result in changes in $\Delta Y$ yield of $<10 \%$ (Table 3 ). There has been a paucity of investigations on selenium species in the Yellow Sea; the DISe concentration in Yellow Sea which was used to calculate the net DISe transport from the Yellow Sea to Sanggou Bay $\left(Y_{\mathrm{X}}\right)$ was obtained by averaging the values of Bohai Sea (Yao \& Zhang 2005) and the East China Sea (Y. Chang et al. unpubl. data). The sensitivity analysis showed that DISe concentration in the Yellow Sea was the most critical parameter and therefore in cases where selenium data are available, it would be worth using a more accurate parameterization of DISe concentration in the Yellow Sea. The DISe concentrations in Sanggou Bay presented significantly variation between seasons and the relative annual mean variation was $42 \%$, which is greater than the $10 \%$ changes for sensitivity analysis. Therefore, in future selenium budget calculation, it may be possible to reduce uncertainty in calculating the budget in seasonal levels. Moreover, the box model's sensitivity to changes in groundwater discharge suggested that any improvement in estimates of groundwater discharge is likely to improve the model accuracy. Finally, the budgets were relatively insensitive to riverine input $\left(Y_{\mathrm{G}}\right)$, atmospheric 
deposition $\left(Y_{\mathrm{P}}\right)$, sediment diffusion $\left(Y_{\mathrm{S}}\right)$, and to biological fluxes. This suggested that inaccuracies in riverine, atmospheric deposition, sediment diffusion and biological data sets have relatively minor impacts on selenium budget calculation, especially in comparison with inaccuracies associated with other model inputs.

\section{CONCLUSION}

Distributions of dissolved inorganic selenium species observed in Sanggou Bay provide relevant information that can be linked to the dynamics and biological reactions that take place in the region. Average concentrations of DISe and Se(IV) in surface waters of the bay were 0.67 and $0.28 \mathrm{nmol}^{-1}$, respectively, with ranges of $0.21-1.36$ and $0.07-0.58 \mathrm{nmol}$ $\mathrm{I}^{-1}$, respectively. The average $\mathrm{Se}(\mathrm{IV}) / \mathrm{Se}(\mathrm{VI})$ ratio was 0.74 , indicating that $\mathrm{Se}(\mathrm{VI})$ was the predominate inorganic selenium species in large proportion of the bay. DISe concentrations in Sanggou Bay remained 2 orders of magnitude below the critical selenium limit for water in China. The highest selenium content was observed in scallops $\left(3.6 \pm 0.7 \mu \mathrm{g} \mathrm{g}^{-1}\right)$, followed by oyster $\left(1.6 \pm 0.4 \mathrm{ug} \mathrm{g}^{-1}\right)$, phytoplankton $(0.9 \pm 0.3$ $\left.\mu \mathrm{g} \mathrm{g}^{-1}\right), G$. lemaneiformis $\left(0.063 \pm 0.008 \mu \mathrm{g} \mathrm{g}^{-1}\right)$ and

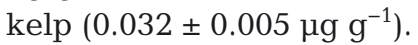

The DISe and Se(IV) concentrations were low in summer and high in spring and autumn. The distribution of DISe and Se(IV) in the bay showed strong horizontal gradients from the coast to offshore. The intensive seaweed and bivalve aquaculture present over large areas had a strong influence on selenium distribution. The Se(IV) concentrations in the seaweed monoculture region were low in spring due to the uptake by the seaweed. While the Se(IV) and $\mathrm{Se}(\mathrm{VI})$ concentrations in the bivalve monoculture region were high in autumn, probably caused by the bivalves assimilating particulate selenium but excreting dissolved selenium, thereby replenishing selenium levels in the water column.

A simple budget for DISe in Sanggou Bay was estimated in this study. The major source of DISe into Sanggou Bay was water exchange with the Yellow Sea. Groundwater discharge was the second largest source of selenium into the bay. However, intensive bivalve aquaculture removed $34 \pm 9 \%$ of the DISe input, making it the most important sink.

Acknowledgements. This study was supported by the National Basic Research Program of China (No. 2011CB 409801). The authors thank Chudao and Xunshan Fisheries Corporations for the help in the field work and providing laboratory. We thank colleagues from Yellow Sea Fisheries Research Institute, East China Normal University and Ocean University of China for the assistance in field observations. Anonymous reviewers and the editor are especially acknowledged for their constructive suggestions, which greatly improved the manuscript.

\section{LITERATURE CITED}

Abdel-Moati M (1998) Speciation of selenium in a Nile Delta Lagoon and SE Mediterranean Sea mixing zone. Estuar Coast Shelf Sci 46:621-628

Ansede JH, Yoch DC (1997) Comparison of selenium and sulfur volatilization by dimethylsulfoniopropionatelyase (DMSP) in two marine bacteria and estuarine sediments. Microb Ecol 23:315-324

Apte S, Howard A, Morris R, McCartney M (1986) Arsenic, antimony and selenium speciation during a spring phytoplankton bloom in a closed experimental ecosystem. Mar Chem 20:119-130

Baines SB, Fisher NS (2001) Interspecific differences in the bioconcentration of selenite by phytoplankton and their ecological implications. Mar Ecol Prog Ser 213:1-12

Baldwin S, Maher W (1997) Spatial and temporal variation of selenium concentration in five species of intertidal molluscs from Jervis Bay, Australia. Mar Environ Res 44: 243-262

Barwick M, Maher W (2003) Biotransference and biomagnification of selenium copper, cadmium, zinc, arsenic and lead in a temperate seagrass ecosystem from Lake Macquarie Estuary, NSW, Australia. Mar Environ Res 56:471-502

Besser JM, Huckins JN, Clark RC (1994) Separation of selenium species released from Se-exposed algae. Chemosphere 29:771-780

Cai LS, Fang JG, Liang XM (2003) Natural sedimentation in large-scale aquaculture areas of Sungo Bay, North China Sea. J Fish Sci China 10:305-310 (in Chinese with English Abstract)

Chang Y, Qu JG, Zhang RF, Zhang J (2014) Determination of inorganic selenium speciation in natural water by sector field inductively coupled plasma mass spectrometry combined with hydride generation. Chin J Anal Chem 42:753-758 (in Chinese with English Abstract)

Conde JE, Sanz Alaejos M (1997) Selenium concentrations in natural and environmental waters. Chem Rev 97: 1979-2004

Cutter GA (1978) Species determination of selenium in natural waters. Anal Chim Acta 98:59-66

Cutter GA, Bruland KW (1984) The marine biogeochemistry of selenium: a re-evaluation. Limnol Oceanogr 29: 1179-1192

Cutter GA, Cutter LS (1995) Behavior of dissolved antimony, arsenic, and selenium in the Atlantic Ocean. Mar Chem 49:295-306

Cutter GA, Cutter LS (2001) Sources and cycling of selenium in the western and equatorial Atlantic Ocean. Deep-Sea Res II 48:2917-2931

Editorial Board of Annals of Bays in China (1991) Annals of bays in China. Ocean Press, Beijing (in Chinese)

Fang JG, Kuang SH, Sun HL, Li F, Zhang AJ, Wang XZ, Tang TY (1996) Mariculture status and optimising measurements for the culture of scallop Chlamys farreri and kelp Laminaria japonica in Sanggou Bay. Mar Fish Res 
17:95-102 (in Chinese with English Abstract)

Fernández-Martínez A, Charlet L (2009) Selenium environmental cycling and bioavailability: a structural chemist point of view. Rev Environ Sci Biotechnol 8:81-110

Fordyce FM (2013) Selenium deficiency and toxicity in the environment. In: Selinus O (ed) Essentials of medical geology. Springer, Amsterdam, p 375-416

$>$ Fries L (1982) Selenium stimulates growth of marine macroalgae in axenic culture. J Phycol 18:328-331

Gordon DC, Boudreau P, Mann K, Ong J and others (1996) LOICZ biogeochemical modelling guidelines, Vol 5. LOICZ Core Project, Netherlands Institute for Sea Research, Texel

Griscom SB, Fisher NS (2004) Bioavailability of sedimentbound metals to marine bivalve molluscs: an overview. Estuaries 27:826-838

Guo XM, Ford SE, Zhang FS (1999) Mollusca aquaculture in China. J Shellfish Res 18:19-31

Hansen D, Duda PJ, Zayed A, Terry N (1998) Selenium removal by constructed wetlands: role of biological volatilization. Environ Sci Technol 32:591-597

> He M, Wang WX (2013) Bioaccessibility of 12 trace elements in marine molluscs. Food Chem Toxicol 55:627-636

Horne AJ (1991) Selenium detoxification in wetlands by permanent flooding: I. Effects on a macroalga, an epiphytic herbivore, and an invertebrate predator in the long-term mesocosm experiment at Kesterson Reservoir, California. Water Air Soil Pollut 57:43-52

Hsu SC, Wong GTF, Gong GC, Shiah FK, and others (2010) Sources, solubility, and dry deposition of aerosol trace elements over the East China Sea. Mar Chem 120: 116-127

> Hu MH, Yang YP, Martin JM, Yin K, Harrison PJ (1997) Preferential uptake of Se(IV) over Se(VI) and the production of dissolved organic Se by marine phytoplankton. Mar Environ Res 44:225-231

Jiang ZJ, Fang JG, Zhang JH, Mao YZ, Wang W (2008) Distribution features and evaluation on potential ecological risk of heavy metals in surface sediments of Sungo Bay. J Agro-Environ Sci 27:0301-0305 (in Chinese with English Abstract)

> Jiang ZJ, Li J, Qiao XD, Wang GH, Bian DP and others (2015) The budget of dissolved inorganic carbon in the shellfish and seaweed integrated mariculture area of Sanggou Bay, Shandong, China. Aquaculture 446:167-174

> Johnson TM, Bullen TD, Zawislanski PT (2000) Selenium stable isotope ratios as indicators of sources and cycling of selenium: results from the northern reach of San Francisco Bay. Environ Sci Technol 34:2075-2079

Lemly AD (1995) A protocol for aquatic hazard assessment of selenium. Ecotoxicol Environ Saf 32:280-288

Li L, Ren JL, Liu SM, Jiang ZJ, Du JZ, Fang JG (2014) Distribution, seasonal variation and influence factors of dissolved inorganic arsenic in the Sanggou Bay. Environ Sci 35:2705-2713 (in Chinese with English Abstract)

> Lin CL, Ning XR, Su JL, Lin Y, Xu B (2005) Environmental changes and the responses of the ecosystems of the Yellow Sea during 1976-2000. J Mar Syst 55:223-234

Lin YH, Shiau SY (2005) Dietary selenium requirements of juvenile grouper, Epinephelus malabaricus. Aquaculture 250:356-363

Liu DL, Yang YP, Hu MH, and others (1987) Selenium content of marine food chain organisms from the coast of China. Mar Environ Res 22:151-165

Liu H, Fang J, Zhu J, Dong S, and others (2004) Study on limiting nutrients and phytoplankton at long-line-culture areas in Laizhou Bay and Sanggou Bay, northeastern China. Aquat Conserv 14:551-574

> Liu SM, Ling WL, Zhang ZN (2011) Inventory of nutrients in the Bohai. Cont Shelf Res 31:1790-1797

Lobanov AV, Hatfield DL, Gladyshev VN (2009) Eukaryotic selenoproteins and selenoproteomes. Biochim Biophys Acta 1790:1424-1428

> Luoma SN, Presser TS (2009) Emerging opportunities in management of selenium contamination. Environ Sci Technol 43:8483-8487

Maher W, Baldwin S, Deaker M, Lrving M (1992) Characteristics of selenium in Australian marine biota. Appl Organomet Chem 6:103-112

> Meseck S, Cutter G (2012) Selenium behavior in San Francisco Bay sediments. Estuaries Coasts 35:646-657

> Moore WS (1996) Large groundwater inputs to coastal waters revealed by ${ }^{226} \mathrm{Ra}$ enrichments. Nature 380:612-614

Ning Z, Liu S, Zhang G, Ning X and others (2016) Impacts of an integrated multi-trophic aquaculture system on benthic nutrient fluxes: a case study in Sanggou Bay, China. Aquacult Environ Interact 8:221-232

> Price NM, Thompson PA, Harrison PJ (1987) Selenium: an essential element for growth of the coastal marine diatom Thalassiosira pseudonana (bacillariophyceae). J Phycol 23:1-9

> Reinfelder J, Wang W, Luoma S, Fisher N (1997) Assimilation efficiencies and turnover rates of trace elements in marine bivalves: a comparison of oysters, clams and mussels. Mar Biol 129:443-452

Rongcheng Fisheries Technology Extension Station (2012) Marine fishery statistics data. Fishery Technology Station of Rongcheng City, Rongcheng

Rotruck JT, Pope A, Ganther H, Swanson A, Hafeman DG, Hoekstra W (1973) Selenium: biochemical role as a component of glutathione peroxidase. Science 179:588-590

Shandong Flourish the Local Chronicles Compilation Committee (1999) Records Rongcheng. Qilu, Jinan (in Chinese)

Sherrard JC, Hunter KA, Boyd PW (2004) Selenium speciation in subantarctic and subtropical waters east of New Zealand: trends and temporal variations. Deep-Sea Res I 51:491-506

Shi J, Wei H, Zhao L, Yuan Y, Fang J, Zhang J (2011) A physical-biological coupled aquaculture model for a suspended aquaculture area of China. Aquaculture 318: $412-424$

Simmons DB, Wallschläger D (2005) A critical review of the biogeochemistry and ecotoxicology of selenium in lotic and lentic environments. Environ Toxicol Chem 24: 1331-1343

State Environmental Protection Administration of China (2002) Environmental quality standards for surface water (GB 3838-2002). China Environmental Science Press, Beijing (in Chinese)

Stüeken EE, Buick R, Bekker A Catling D and others (2015) The evolution of the global selenium cycle: secular trends in Se isotopes and abundances. Geochim Cosmochim Acta 162:109-125

Ullman WJ, Aller RC (1982) Diffusion coefficients in nearshore marine sediments. Limnol Oceanogr 27:552-556

Vandermeulen J, Foda A (1988) Cycling of selenite and selenate in marine phytoplankton. Mar Biol 98:115-123

Wang WX, Fisher NS (1996) Assimilation of trace elements and carbon by the mussel mytilus edulis: effects of food 
composition. Limnol Oceanogr 41:197-207

> Wang XL, Du JZ, Ji T, Wen TY, Liu SM, Zhang J (2014) An estimation of nutrient fluxes via submarine groundwater discharge into the Sanggou Bay - a typical multi-species culture ecosystem in China. Mar Chem 167:113-122

Yan X, Zheng L, Chen H, Lin W, Zhang W (2004) Enriched accumulation and biotransformation of selenium in the edible seaweed Laminaria japonica. J Agric Food Chem 52:6460-6464

Yao QZ, Zhang J (2003) Salt effect on the determination of inorganic selenium in natural water and its modified method. J Ocean Univ Qingdao 33:765-880 (in Chinese with English abstract)

Yao QZ, Zhang J (2005) The behavior of dissolved inorganic selenium in the Bohai Sea. Estuar Coast Shelf Sci 63: 333-347

Zhang LS, Combs SM (1996) Using the installed spray chamber as a gas-liquid separator for the determination

Editorial responsibility: Sebastien Lefebvre (Guest Editor), Wimereux, France of germanium, arsenic, selenium, tin, antimony, tellurium and bismuth by hydride generation inductively coupled plasma mass spectrometry. J Anal At Spectrom 11:1043-1048

Zhang J, Hansen PK, Fang J, Wang W, Jiang Z (2009) Assessment of the local environmental impact of intensive marine shellfish and seaweed farming - application of the MOM system in the Sungo Bay, China. Aquaculture 287:304-310

Zhao J, Zhou S, Sun Y, Fang J (1996) Research on Sanggou Bay aquaculture hydro-environment. Mar Fish Res 17: 68-79 (in Chinese with English Abstract)

Zheng W, Shi H, Chen S, Zhu M (2009) Benefit and cost analysis of mariculture based on ecosystem services. Ecol Econ 68:1626-1632

Zhu F, Tan J (1988) Selenium, iodine and fluorine in rainwater and dustfall in China. Acta Sci Circumst 8:428-437 (in Chinese with English Abstract)

Submitted: June 3, 2015; Accepted: December 9, 2015

Proofs received from author(s): January 20, 2016 